\title{
Quo Vadis Government Policy To Achieve National Food Security: An Evaluation of The VAT Policy Development on Poultry Products
}

\author{
Torganda Raymundus ${ }^{1}$, Haula Rosdiana ${ }^{2}$ Inayati $^{3}$ \\ torgandasitohang@gmail.com ${ }^{1}$,haularosdiana71@gmail.com², inayati.hifni01@gmail.com³ \\ Administrative Sciences, Administration and Tax Policy, Faculty of Administrative Sciences \\ Universitas Indonesia ${ }^{1}$, Department of Fiscal Administration, Faculty of Administrative Science, \\ Universitas Indonesia ${ }^{2}$
}

\begin{abstract}
Food security has become the concern of countries in the world as stated in the sustainable development goals (SDGs). In the national context, food security and stunting issues are a serious problem that requires an immediate response from the government of Indonesia. However, the government's policy to tackle the issue is still incomprehensive. This research describes the Value Added Tax (VAT) policy development on poultry products to achieve national food security. There are three issues of the VAT policy development on poultry sector, i.e. the incompatibility issue of the design of theVAT object determination to the cost of taxation and revenue productivity principles, issue on the VAT administration which contradicts to the ease of administration principle, and the productivity issue from the supply-side tax policy perspective.
\end{abstract}

Keywords: VAT; tax policy; poultry product; Supply-Side Tax Policy, Cost Of Taxation

\section{Introduction}

The food security issue has become the concern of many countries in the world and covered in the Sustainable Development Goals (SDGs). There are 17 points of development goals approved by countries in the world with 169 quantified goals as the main agenda of the United Nations to achieve a better and sustainable future for all. Among the set goals, the second point of the SDGs, that is to achieve zero hunger has become an important focus, due to the significant importance as a foundation for other development sectors and to achieve the national welfare. Referring to the research by Grebmer (2018) [1], Indonesia indicates an unsatisfying condition related to food security. The research by the Global Hunger Index (GHI) in 2018 reveals that Indonesia received 21,9 index score on hunger and malnutrition which is lower by 2,6 points from the GHI in 2010 . This score has placed Indonesia as a country with a very poor level of hunger in the world. The index score for Indonesia is one of the lowest scores in ASEAN. Recently, stunting has also become a challenge in relation to the food security issue. Stunting in Indonesia is rising at an alarming rate reaching to 26,4\% prevalence in 2015 and $36 \%$ in 2017 which is the fourth highest in the world.

The issues of hunger and fulfilling the needs of nutrients, particularly protein and fat to eradicate stunting and ensure food security in Indonesia could be overcome by consuming a 
good combination of various sources of protein and fat, particularly protein from poultry products. The selection of the protein sources from poultry is reasonable as it is cheaper and contains relatively similar protein types compared to beef, which is more expensive. Moreover, the government has encouraged to increase the poultry product consumption, specifically through fiscal policy. The fiscal policy instrument used by the government varies from subsidy to taxation policy. For taxation policy, the government released several forms of taxation policy to improve the citizens' consumption on poultry products, including the VAT policy. The VAT policy on poultry products released by the government has been through several transformations. In the beginning, the VAT on poultry products was initially categorized as nontaxable goods but then was changed into taxable goods with exemption facility. Recently, VAT policy for poultry products according to the Law No. 42 the year of 2009 on the Third Alteration of Law No. 8 the year of 1983 on the VAT and Sales Tax on Luxurious Goods treated as nontaxable goods. Looking at the VAT policy development on poultry sector since the regime of the VAT Law of the year of 1983 to the VAT Law of the year of 2009 which is still effective to this moment, there has not been any evaluation despite the potential weaknesses and strengths of each Law.

Referring to the description above, this research aims to: a) Evaluate the VAT policy development on poultry products according to the VAT Law regimes in Indonesia; b) Describe the strengths and weaknesses of each VAT policy of the VAT Law regimes.

\section{Literature Review}

This research utilizes several taxation concepts and theories to develop a framework, i.e. public policy evaluation concept, the tax collection concept, VAT and supply-side tax policy concepts. The VAT concept used in the research includes the legal characters of the VAT, the calculation method of the VAT, and VAT facilities. Legal characters are defined as the characteristics or the nature of a particular tax (Rosdiana, Irianto, Putranti, 2011, p. 43-44) [2]. The VAT legal characters covered in this research to support the theory include the general tax on consumption, indirect tax and neutral (Terra, 1988, p. 5-19) [3].

Besides the VAT legal character, the research also uses the tax exemption concept of the VAT. Exemption is a method to exclude particular goods or service delivery from the VAT due to the not-payable delivery, thus the VAT imposed on the entrepreneurs during the goods and service purchase of the VAT-exempted goods and service delivery cannot be credited and becomes the cost unit if the purchase is not made by the final consumer (Tait, 1988, p. 50) [4]. The tax exemption has become more diverse and granted to attract entrepreneurs to invest in a particular area.

In addition to tax exemption, the research also uses the concept of the taxable goods as an important basic concept, as mentioned by Rosdiana et.al. (2011:111) [5], stating that there are several things to consider in designing policy for taxable goods. Moreover, there are few things to consider before deciding whether particular goods deserve to become the taxable goods or not, i.e. 1) the compatibility to the legal character, 2) suitability with the principle of revenue productivity, 2) cost of taxation consideration and 3) suitability with the ease of administration principle.

Furthermore, as stated by Rosdiana and Irianto, the supply-side tax policy concept (Rosdiana and Irianto, 2012, 85-86) [6] is a policy directed to improve the market performance by increasing the economic capacity to produce, thus will lead to the rise of the demand curve. The policy could be used to reduce market imperfection in an attempt to improve industrial productivity (Chattopadhyay \& DasGupta, 2002) [7]. This is compatible with the research result on the journal-title "Supply-side Tax Policy Reconstruction Conception" by Rosdiana (2008) 
[8]. This journal article discusses the basic philosophy of the supply-side tax policy conception which emphasizes on the policy to minimize the market distortion as a result of government regulation impact on prices, subsidy and the high income tax rate; as well as the policy urge on investment and production by ensuring the free market economy incentive to work.

The essence of supply-side tax policy conception includes (1) the taxation policy regulations that have not been regulated or unclear, (2) the taxation policy deregulation that leads to the high cost of taxation, and (3) taxation policy deregulation that disrupt the cash flow as parts of supply-side tax policy conception. These three forms of the supply-side tax policy led to one conception, known as the cost of taxation. The essence of supply-side tax policy and cost of taxation is the policy to reduce the cost of taxation through re-regulations and deregulations and can be viewed as a part of the supply-side tax policy. This was based on the belief that the high cost of taxation will reduce the space for the entrepreneurs to produce, thus reducing the supply. Regulation of tax treatment on transactions that are not yet occurred or under an unclear tax regulation could reduce the cost of taxation as it could minimize the potential for dispute. The decrease of the potential dispute also means the reduction of time cost and psychological cost in submitting an objection and/or an appeal, from the taxpayer as well as the tax authority side. Moreover, the fiscal costs or direct money costs paid by both sides often become higher following the needs to hire an expert/consultant/legal representation and others. Deregulation of the tax regulation also leads to the higher cost of taxation, which could be considered as a part of supply-side tax policy (Rosdiana, 2008 p.202) [8].

Another concept in this research related to the concept of the hierarchy in the law system introduced by Hans Kelsen, that regulates the relationship between norms which administers other norms' act as the other norms could be named as super and sub-ordinance relationships in the spatial context (Asshiddiqie:2006) [9]. The Hans Kelsen theory of the hierarchy in the law system was inspired by Adolf Merkl who utilized the das doppelte rech stanilitz theory, a law with two faces which means that a particular law is sourced and founded by the upper norm and becomes the foundation and a source for the lower norm (Farida:1998) [10]. Further, according to this theory, a law postulate lex superior derogate legi inferiori is valid, which means a particular law with higher rank could negate the regulation at the lower rank, only if the substances of the higher ranked regulation administers things that is according to the Law is under the authority of the lower ranked regulation (Manan:2004) [11].

In this research, the tax policy analysis focuses on the VAT policy as a form of public policy directed to achieve a particular goal. There are several approaches available for public policy evaluation. This research uses a formal evaluation by using a descriptive method to acquire valid and reliable information on policy results and evaluate the results according to the policy program objective that has been released by the policymaker (Dunn, 2003, Nugroho, 2011 p. 613) [12], [13]. The formal evaluation in this research is normative, which means the evaluation is conducted to monitor the formal objective and target achievement after the implementation of particular policy or program for a certain period of time. In this case, the VAT policy on the poultry sector has been implemented since the regime of the VAT Law No. 11 the year of 1994. In harmony with the formal evaluation variation mentioned by William Dunn (2011:615) [12], this research focuses on the development evaluation which refers to the explicit evaluation activity to avert the weaknesses or failures of a program and ensure whether a particular program is credible or not. The development evaluation in this research is conducted 
to observe the VAT policy development on the poultry sector according to the regime of the VAT Law and describe the weaknesses and strengths of each regime of Law.

\section{Method}

This study applied a qualitative approach with inductive reasoning. The authors describe social phenomena by prioritizing social realities found in the study (Wagner, 2012) [14]. A good research design that meets scientific standards shall be followed by a relevant theoretical study or perspective to help understand and describe the social phenomena focused on (Bungin, 2002, p. 45, Creswell, 1998, Neuman, 2000) [15], [16], [17]. Data collection techniques applied were field study and documentation study with qualitative data analysis. The field study was carried out through in-depth interviews with the informants formulating the policy, namely the Fiscal Policy Agency (BKF), and the informants implementing the policy, namely the Directorate General of Taxes (DJP), the National Poultry Association (GPMT and GOPAN) as an association of several chicken farmer companies in Indonesia, and an integrated poultry producer, namely PT CPI.

\section{Discussion}

The VAT policy on the poultry sector generally divided into two major groups, i.e. non taxable goods policy on meat products and eggs as well as the exemption policy on several inputs used in the poultry supply chain. This research discusses the VAT policy development evaluation on poultry products that includes meat and eggs according to the regime of the VAT Law since 1983, under the Law No.8 year of 1983, to the regime of the VAT Law No.42 year of 2009 along with other regulations according to the law hierarchy in Indonesia from the conceptual perspective as described previously in the literature review. The detailed discussions are presented in the following subsections.

\section{A. The VAT Policy Development Evaluation on Poultry Products According to The Regime of the VAT Law}

\section{A.1 The VAT Policy Development Evaluation on Poultry Products Under The Regime of the Law No. 8 the Year of 1983}

In the regime of Law No. 8 the year of 1983, there were no clear and specific regulations for VAT policy on poultry products. However, the definition of taxable goods mentioned in Article 1 alphabet $\mathrm{c}$ of the Law No.8 year of 1983 emphasizes on the importance of the fabrication process to decide whether particular goods are taxable or not. Besides, Article 1 alphabet $\mathrm{m}$ of the Law No.8 year of 1983 also describes the definition of producing, that is an activity to turn something through a process of changing the form or characteristics of particular goods from the original form into new goods or to have a new function. According to this definition, particularly article 1 alphabet $\mathrm{m}$ and number 1 , animal breeding is not considered as producing.

The elucidation section of the Law also mentions that all goods from farming, plantation, forestry, fishery, animal husbandry, and other unproduced agrarian products are not taxable goods. Moreover, the section of the elucidation of law for article 1 alphabet $\mathrm{c}$ also mention that the unproduced goods from animal husbandry are not considered as taxable goods according to the Law. Further, article 1 alphabet $\mathrm{m}$ of the Law also mentions that any business activity in the 
agrarian sector, including husbandry which products are gained from growing process or population (non-production) and highly influenced by natural factor, are not taxable.

The government regulation No.22 year of 1985 also reaffirms the VAT treatment on husbandry as stated on the VAT Law No. 8 the year of 1983, specifically in article 11 verse (1) alphabet $\mathrm{b}$. The article explains that animal husbandry includes the activity of slicing livestock products as mentioned in article 1 alphabet $m$ number 1 , using hands or other means.

According to the aforementioned law products, the animal husbandry that produces poultry is an activity that creates non-taxable goods. However, there is no clear VAT policy implemented on poultry products, such as meat and eggs. Although slicing is considered as a part of the activity to produce poultry products such as poultry meat, there should be legal certainty and clarity for this activity since the beginning of the enactment of the VAT Law.

The government regulation which defines the "slicing" activity as a part of the animal husbandry definition is in contradiction to the legal interpretation principle of lex superior derogate legi inferiori. It is in harmony with the principle, if the substances of the higher rank law according to the law is defined to administer things which are under the authority of the lower rank law. In this case, article 1 of the VAT Law No.8 year of 1983 and its elucidation does not grant any authority in other government regulation to interpret the definition of "breeding the livestock". This will potentially raise the compliance cost and tax dispute, which is a type of cost of taxation during its implementation as there is no further elaboration on the "fabrication" clausal mentioned in the Law, the elucidation of the law section or other derived regulations. The clausal has become contra-productive to the development efforts in the poultry sector, particularly in the modernization of the poultry industry. Nevertheless, there are some strengths of the policy on poultry products due to its open list characteristics despite its limitation related to the "non-fabrication" clausal. The following figure depicts the policy gap on the poultry products.

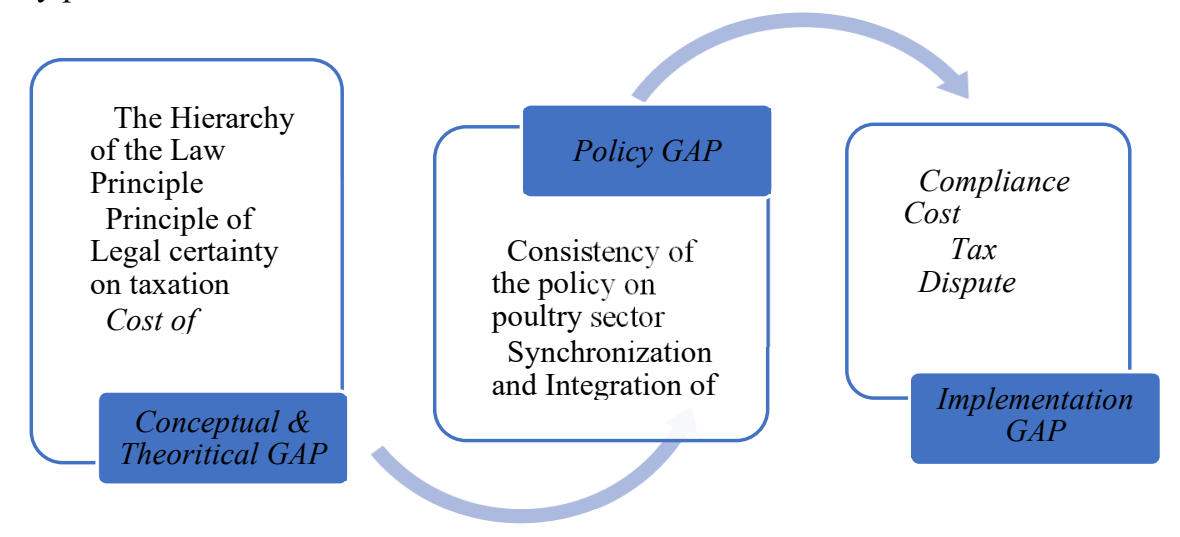

Figure 1. VAT Policy Process on Poultry Products in the Regime of the ACT on VAT No. 8 the Year of 1983

Source: Processed by the researcher

\section{A.2 VAT Policy Development Evaluation on Poultry Products In the Regime of the Law No. 11 the Year of 1994}

The regime of the Law No. 11 the year of 1994 provides more detailed VAT treatment on poultry products. The new article $4 \mathrm{~A}$ was added to the law which was not available in the previous Law No.8 year of 1983. According to this article and its elucidation, the goods from 
husbandry, hunting/catching or breeding, which are directly obtained from the source, such as livestock and poultry are further regulated in the Government Regulation. The type of the nontaxable goods is regulated under the Government Regulation No. 50 the year of 1994 on the Implementation of the Law No. 8 the year of 1983 on VAT and Sales Tax on Luxurious Goods, that has been modified in the Law No. 11 the year of 1994. Article 3 number 2 of the regulation reaffirms that the husbandry products are not subject to VAT. Article 5 number 1 alphabet a further regulates detailed coverage of "directly obtained from the source" clausal which includes seeding and cultivation of the poultry such as chicken, ducks, quails, turkeys, and others as well as the eggs.

The changes in the regime of the law and government regulation indicate a significant and progressive improvement in the non-taxable goods regulation for poultry products. The Law No. 11 the year of 1994 and Government regulation No. 50 the year of 1994 has reflected the principles of legal certainty and the hierarchy in the law as it has fulfilled the principle of lex superior derogat legi inferiori. Furthermore, the regulation on the husbandry products which are non-taxable goods has depicted a more open list character, as reflected in article 5 number 1 alphabet e of the Government Regulation No. 50 the year of 1994. The regulation in article 3 number 2 and article 5 number 1 alphabet a of the Government Regulation No. 50 the year of 1994 are not conflicting with article 4A of the Law No. 11 the year of 1994 and its elucidation. This is because the substances of the regulation do not overlap with what has been regulated in the law, particularly related to the "directly obtained from the source" clausal. Both regulations affirm that poultry products are non-taxable goods. However, referring to the articles mentioned above, the law and regulations that administer the activities to produce goods from husbandry have not clearly and specifically described the VAT policy on poultry products. This could potentially raise the significantly high cost of taxation on activities to produce poultry products during this regime of law as a result of the absence of clear and certain legal standards to regulate the policy on poultry products.

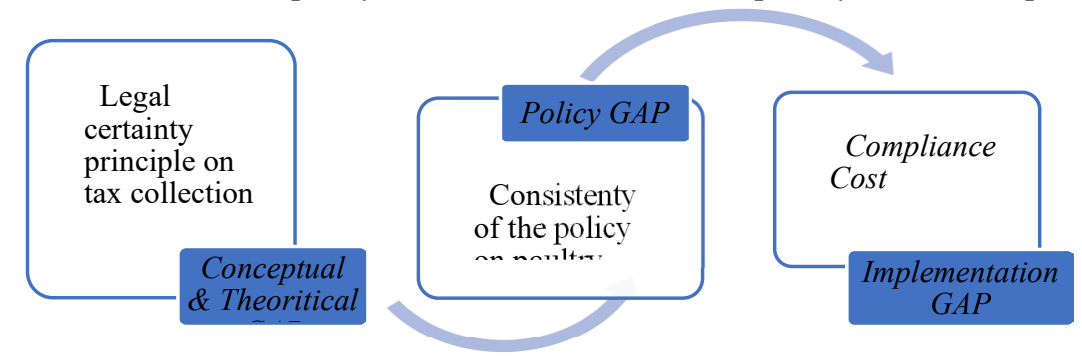

Figure 2. The VAT Policy Process on Poultry Products In the Regime of The ACT on VAT No. 11 the Year of 1994

Source: Processed by the researcher

\section{A.3 VAT Policy Development Evaluation on Poultry Products in The Regime of the Law No. 18 the Year of 2000}

Regulation to determine the non-taxable goods according to the regime of this law still uses the same article 4A. However, there is a significant change compared to the previous regime. Although the VAT Law in this regime still provides the authority to determine the nontaxable goods through the government regulation article 4A verse (1) of Law No.18 year of 2000 , the authority is limited by the rules as mentioned in article 4A verse (2). Referring to article 4 verse (2), there are 4 (four) groups of non-taxable goods. Following the article $4 \mathrm{~A}$ verse (1) and (2) as well as its elucidation, the activity of producing poultry products, including 
poultry, eggs, and poultry meat are not the types of non-taxable goods. This means those poultry products are subject to VAT according to the regime of this law. The derivative legal products of this law include the Government Regulation No. 143 the year of 2000 with the most recent modification in the government regulation No. 24 the year of 2000 which also exclude poultry products from non-taxable goods category.

However, the VAT treatment on the poultry sector still receives special attention. This is in harmony with article 16B and its elucidation which provides easier tax treatment to encourage national development by providing particular goods that are considered strategic according to the Government regulation. Referring to the government regulation No. 12 year of 2001 along with its recent modification in the Government Regulation of Indonesia No.7 year of 2007, the third modification on the Government Regulation No. 12 year of 2001 on Import and/or Particular Strategic Taxable Goods Delivery with VAT exemption, specifically in article 1 no. 2 alphabet $\mathrm{c}$ and article 1 no.2 alphabet $\mathrm{b}$, goods from agricultural production are considered strategic. These include goods from several agricultural sectors such as the animal husbandry. Regulation on husbandry goods that receive VAT exemption is further stated in the Regulation of the Ministry of Finance No. 155/KMK.03/2001, with recent modification in the Regulation of the Ministry of Finance No. 11/PMK.03/2007 on the third modification of the Decree of the Ministry of Finance No. 155/KMK.03/2001 on the VAT Exemption on Imports and/or Strategic Taxable Goods Delivery. According to article 1 no.2 alphabet B of this regulation, the husbandry products receive the VAT exemption.

The determination of the husbandry products as taxable goods with VAT exemption facility according to the regime of this law has changed two things. Firstly, the determination of the non-taxable goods according to article 4A of this law has changed compared to the previous characteristic which was opened list, to become a closed list. Therefore, the animal husbandry products are no longer non-taxable goods as stated in article 4A verse 2 of the Law No. 18 the year of 2000. Moreover, the decision to change the husbandry products to be the taxable goods with exemption facility has also changed the VAT conception on husbandry products. In the past, all husbandry products were non-taxable goods, but in this law regime, the products have conceptually become taxable goods with exemption facility.

Secondly, the conceptual difference will increase the burden of the entrepreneurs in the animal husbandry sector. Due to the determination of the taxable goods in this sector, the entrepreneurs are obliged to fulfill their tax obligations according to article $3 \mathrm{~A}$ verse (1) of the Law No. 18 year of 2000 although the delivery of the goods is not subject to payable VAT. Conceptually, the determination of the taxable goods in this sector is conflicting with the VAT object determination policy design that should consider the ease of administration and cost of taxation principles. In this case, the simplicity indicator as a part of the ease of administration principle is not fulfilled, since the policy implementation is becoming more complicated along with the VAT administration procedure, as regulated in article $3 \mathrm{~A}$ verse (1) that should be fulfilled by the husbandry entrepreneurs. Consequently, this will raise the cost of taxation in the form of compliance cost for the entrepreneurs, who were not required to do the administration previously. This could also lead to frauds from the entrepreneurs' side due to their lack of understanding to perform the VAT obligation and eventually leads to potential disobedience as well as collection cost for the tax authority as they have to conduct tax audit for this case. The increasing cost of taxation is also conflicting with the supply-side tax policy concept which focuses on productivity improvement, one of them is by re-applying the tax regulations that are subject to dispute. In this case, the dispute could take place due to the lack of understanding on the taxable entrepreneur side to fulfill their tax obligations, particularly in the VAT sector, which causes mistakes in the implementation and eventually leads to the tax dispute between the 
taxable entrepreneur and the tax authority on the implementation of particular tax regulations. The potential dispute that could emerge is related to the input VAT credit on the exempted taxable goods delivery. The lack of understanding of the VAT obligation including the input VAT credit mechanism will potentially lead to a dispute between the taxable entrepreneurs and the tax authority. Further, the dispute will require a tax audit to ensure the VAT obligation fulfillment. In general, the following figure describes the policy and policy gap during the regime of the Law No.18 year of 2000 .

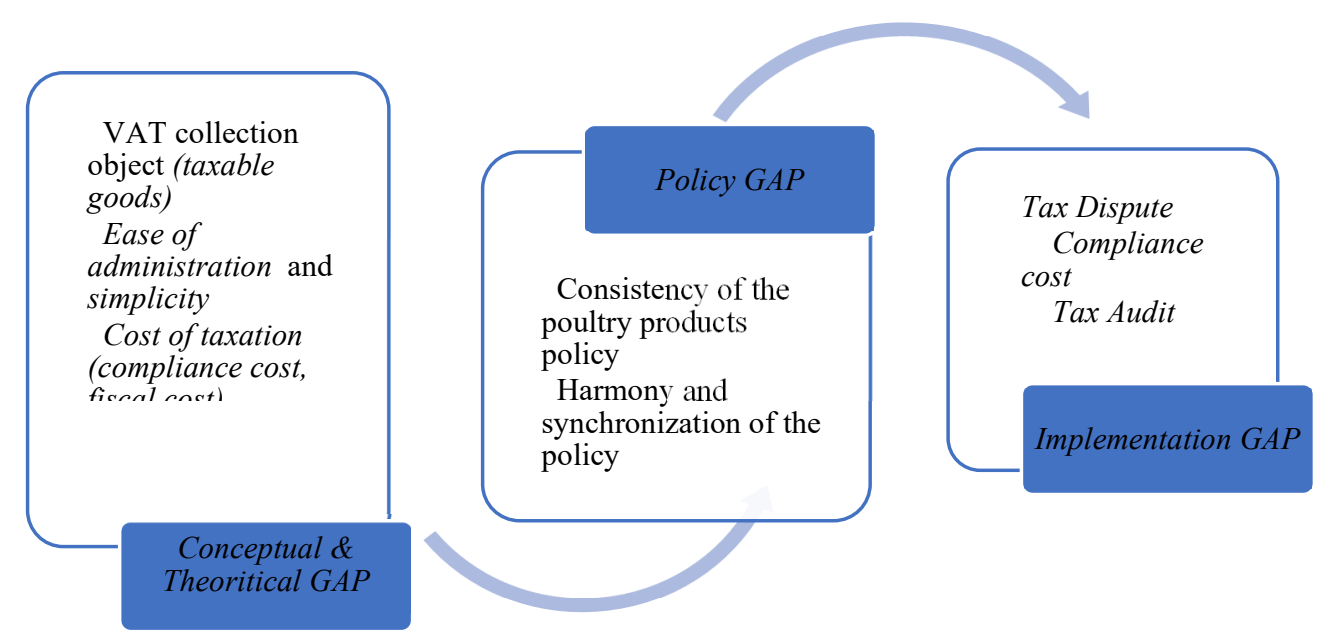

Figure 3. VAT Policy Process on Poultry Products in The Regime of Law No. 18 the Year of 2000 Source: Processed by the researcher

\section{A.4 VAT Policy Development Evaluation on Poultry Products in The Regime of the Law No. 42 the Year of 2009}

In this regime of law, the VAT treatment on poultry products has also changed. Unlike the regime of Law No. 18 the year of 2000, the VAT treatment on poultry products in this regime was re-allocated to the non-taxable goods category. In general, the regulation on the non-taxable goods classification is stated in Article 4A verse (2) of the Law No. 42 the year of 2009 which still categorizes the sector into four categories as stated in the regime of the Law No. 18, the year of 2000. In this regime of law, the tax treatment on poultry products is categorized into groups of goods that are the basic commodities for the citizens as stated in the elucidation of article $4 \mathrm{~A}$ verse (2) alphabet $\mathrm{b}$. The elucidation section of article $4 \mathrm{~A}$ verse (2) alphabet $\mathrm{b}$ describes the types of basic commodities for the citizens consists of eleven types of goods, including meat and eggs as mentioned in the elucidation of article $4 \mathrm{~A}$ verse 2 alphabet $\mathrm{b}$ point $\mathrm{g}$ and $\mathrm{h}$.

The VAT policy on meat and eggs which are the products of husbandry reflects a specific regulation. Specific policy on poultry products could be applied by separating the husbandry production process (the activity to produce poultry) and the products of husbandry (such as meat and eggs). The VAT policy on poultry products such as meat and eggs is in harmony with the regime of the law which has an opened list characteristics, thus relatively easier to be implemented and fits better to the ease of administration principle. On the other hand, the determination of the non-taxable good on meat and eggs has also followed the policy design on the VAT object determination by considering the ease of administration and cost of taxation principles. By applying this policy, the compliance burden for the taxable entrepreneurs due to 
the complexity of VAT obligation fulfillment could be minimized as the goods produced are considered non-taxable. Therefore, the entrepreneurs are not required to report their business to determine their status as a taxable entrepreneur and the obligation to collect, pay and report the VAT and Sales Tax on Luxurious Goods are no longer valid. Referring to the hierarchy of the Law, the policy also reflects a certain goal, particularly to achieve food security by specifically targeting meat and eggs products.

\section{B. Strengths and Weaknesses of Each VAT Policy on Poultry Products during The Regime of The VAT Law in Indonesia}

There have been some changes over the time on the VAT policies on poultry products in Indonesia as previously described in the discussion above. In general, the following picture describes the transformation of the VAT policy on poultry products in Indonesia.

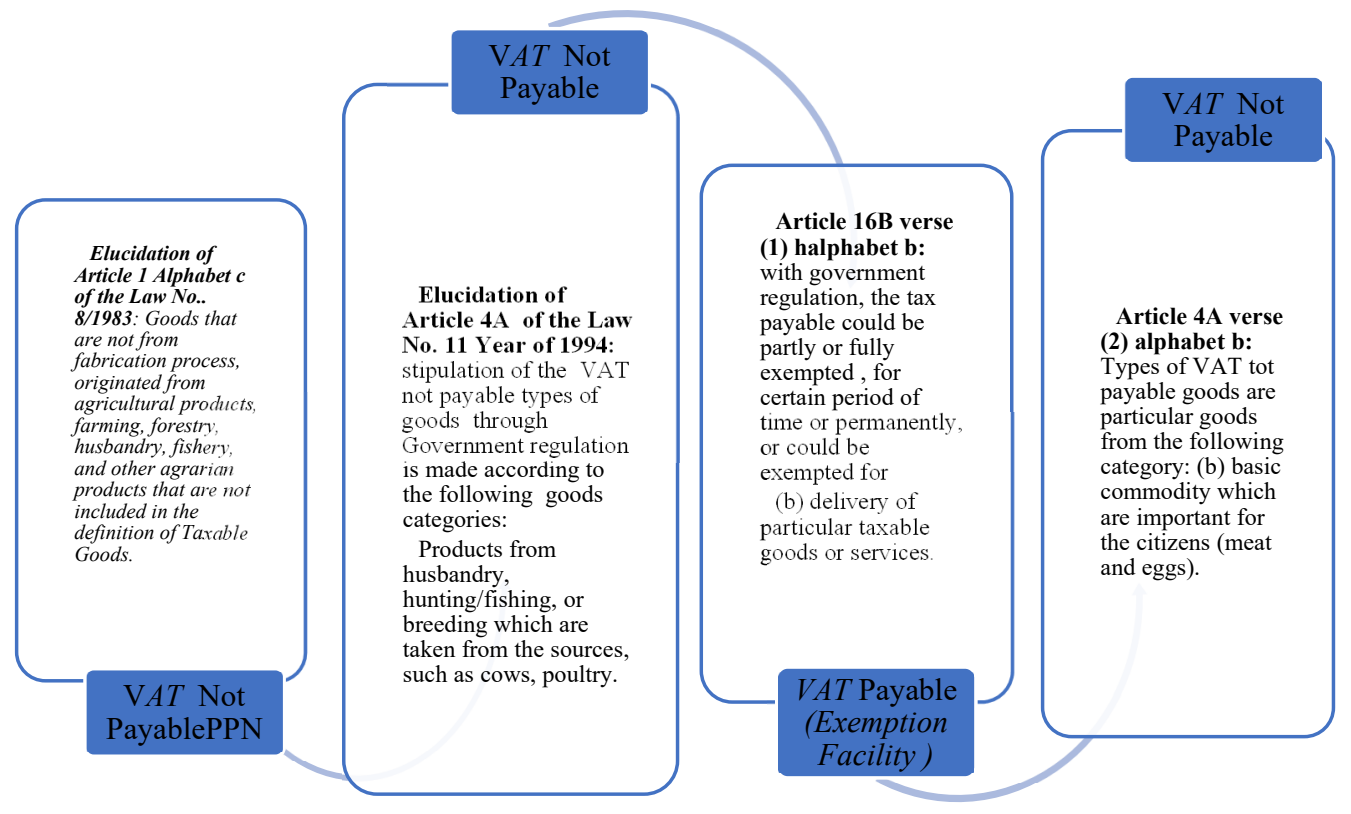

Figure 4. The Policy Structure Development of the VAT Policy on Poultry Products in Indonesia

Source: Processed by the researcher

According to the figure above, the regime of the VAT Law in Indonesia generally incline to implement non-tax payable policy (non-taxable goods) on poultry products. Historically, the modification during the regime of the Law No. 18 the year of 2000 leads to various conceptual, policy and implementation problems as depicted in Figure 3. Moreover, the VAT not payable on poultry products (non taxable goods) has been continuously modified since the beginning of its enactment in the regime of the VAT Law No. 8 year of 1983 which was more general and non specific and becoming more specific on poultry products as stated in the Law No. 42 year 
of 2009. Further, the following table depicts the strengths and weaknesses of the policy structure development selected by the Government in several regimes of the VAT Laws.

Table 1. The Comparison of VAT Policies on Poultry Products in Various Regimes of the VAT

\begin{tabular}{|c|c|c|c|c|}
\hline \multicolumn{5}{|c|}{ Laws in Indonesia } \\
\hline Regulation & $\begin{array}{c}\text { Government } \\
\text { Regulation } \\
\text { No. } 22 \text { The Year of } \\
1985\end{array}$ & $\begin{array}{c}\text { Government } \\
\text { Regulation } \\
\text { No. } 50 \text { the Year of } \\
1994\end{array}$ & $\begin{array}{c}\text { Government } \\
\text { Regulation } \\
\text { No. } 12 \text { the Year of } \\
2001\end{array}$ & $\begin{array}{c}\text { Government } \\
\text { Regulation } \\
\text { No. } 1 \text { the Year of } \\
2012\end{array}$ \\
\hline $\begin{array}{l}\text { Non- } \\
\text { taxable } \\
\text { goods or } \\
\text { VAT } \\
\text { exempt }\end{array}$ & $\begin{array}{l}\text { Goods produced by } \\
\text { husbandry which } \\
\text { are sliced and from } \\
\text { non-fabrication } \\
\text { activities }\end{array}$ & $\begin{array}{l}\text { Goods produced by } \\
\text { husbandry, directly } \\
\text { obtained from the } \\
\text { source, which } \\
\text { includes seeding } \\
\text { and farming of the } \\
\text { poultry such as } \\
\text { duck, chicken, } \\
\text { quail, dove, turkey, } \\
\text { and others, as well } \\
\text { as the eggs. }\end{array}$ & $\begin{array}{l}\text { Particular taxable } \\
\text { goods which are } \\
\text { strategic goods that } \\
\text { is an agricultural } \\
\text { product from } \\
\text { activities in the } \\
\text { husbandry sector. }\end{array}$ & $\begin{array}{l}\text { As stated in Article } \\
4 \text { A of the VAT } \\
\text { Law No. } 42 \text { the } \\
\text { year of } 2009 \text {, that is } \\
\text { basic commodities } \\
\text { necessary for the } \\
\text { citizens }\end{array}$ \\
\hline Policy form & $\begin{array}{l}\text { VAT Not Payable } \\
\text { (non-taxable goods) }\end{array}$ & $\begin{array}{l}\text { VAT not payable } \\
\text { (non-taxable } \\
\text { goods) }\end{array}$ & $\begin{array}{l}\text { The VAT payable } \\
\text { (taxable goods) } \\
\text { with exemption }\end{array}$ & $\begin{array}{l}\text { VAT not payable } \\
\text { (Non-taxable } \\
\text { goods) }\end{array}$ \\
\hline $\begin{array}{l}\text { The VAT } \\
\text { Policy } \\
\text { Object }\end{array}$ & $\begin{array}{l}\text { Imports dan } \\
\text { delivery }\end{array}$ & $\begin{array}{l}\text { Imports dan } \\
\text { delivery }\end{array}$ & $\begin{array}{l}\text { Imports dan } \\
\text { delivery }\end{array}$ & $\begin{array}{l}\text { Imports dan } \\
\text { delivery }\end{array}$ \\
\hline $\begin{array}{l}\text { Date of the } \\
\text { Law }\end{array}$ & 13 March 1985 & 28 December 1994 & 22 March 2001 & 4 January 2012 \\
\hline Date valid & 1 April 1985. & 1 January 1995 & $\begin{array}{l}\text { 1 January } 2001 \\
\text { (effective } \\
\text { retroactively) }\end{array}$ & 4 January 2012 \\
\hline Strengths & $\begin{array}{l}\text { An opened list } \\
\text { object limited to } \\
\text { non-fabrication } \\
\text { activity }\end{array}$ & $\begin{array}{l}\text { - Hierarchical } \\
\text { - Opened list }\end{array}$ & $\begin{array}{l}\text { - Hierarchical } \\
\text { - Lower to upper } \\
\text { policies on } \\
\text { poultry products } \\
\text { are synchronized } \\
\text { (same policy } \\
\text { forms, i.e. VAT } \\
\text { exempted) }\end{array}$ & $\begin{array}{l}\text { - Hierarchical } \\
\text { - Opened list } \\
\text { although specific } \\
\text { to particular } \\
\text { poultry products, } \\
\text { i.e. meat and } \\
\text { eggs } \\
\text { - Not conflicting } \\
\text { with the VAT } \\
\text { object selection } \\
\text { policy design } \\
\text { which does not } \\
\text { consider the ease } \\
\text { of administration } \\
\text { (simplicity) cost } \\
\text { of taxation } \\
\text { principles }\end{array}$ \\
\hline Weaknesses & $\begin{array}{l}\text { - In compliance } \\
\text { with the } \\
\text { hierarchy of the } \\
\text { law }\end{array}$ & $\begin{array}{l}\text { - Potential to raise } \\
\text { the cost of } \\
\text { taxation in the } \\
\text { form of } \\
\text { compliance cost }\end{array}$ & $\begin{array}{l}\text { - Closed list } \\
\text { - Conflicting with } \\
\text { the VAT object } \\
\text { selection policy } \\
\text { design and does }\end{array}$ & $\begin{array}{l}\text { Lower to upper } \\
\text { policies on } \\
\text { poultry products } \\
\text { have not been } \\
\text { synchronized }\end{array}$ \\
\hline
\end{tabular}




\begin{tabular}{|c|c|c|c|}
\hline $\begin{array}{l}\text { Potential to raise } \\
\text { the cost of } \\
\text { taxation in the } \\
\text { form of } \\
\text { compliance cost } \\
\text { from the tax } \\
\text { dispute as a } \\
\text { result of legal } \\
\text { indistinctness } \\
\text { and uncertainty }\end{array}$ & $\begin{array}{l}\text { from the tax } \\
\text { dispute as a } \\
\text { result of legal } \\
\text { indistinctness } \\
\text { and uncertainty }\end{array}$ & $\begin{array}{l}\text { not consider the } \\
\text { ease of } \\
\text { administration } \\
\text { (simplicity) and } \\
\text { cost of taxation } \\
\text { principles } \\
\text { - Potentially raise } \\
\text { the cost of } \\
\text { taxation in the } \\
\text { form of } \\
\text { compliance cost } \\
\text { due to tax } \\
\text { dispute as a } \\
\text { result of lack of } \\
\text { understanding in } \\
\text { the } \\
\text { implementation } \\
\text { of the VAT } \\
\text { obligations }\end{array}$ & $\begin{array}{l}\text { (different policy } \\
\text { forms for poultry } \\
\text { products, i.e. } \\
\text { VAT not payable } \\
\text { for meat and } \\
\text { eggs and VAT } \\
\text { exemption for } \\
\text { several inputs in } \\
\text { the poultry } \\
\text { production } \\
\text { process) }\end{array}$ \\
\hline
\end{tabular}

Source: Processed by the researcher

The table above depicts the VAT policy development on poultry products which has been through several modifications, particularly related to its relevance with the hierarchy of the law. Also, various forms of the policies are mainly opened list, despite several limitations on particular issues. Nevertheless, policy development is still unable to tackle the issue of the potential cost of taxation according to the supply-side tax policy concept since the beginning of the VAT Law regime in Indonesia. The potential cost of taxation still can be found in the table above despite the continuous improvement in each VAT Law regime in Indonesia. The cost of taxation only changes its form and the improvements are still unable to optimally eliminate the issue throughout the VAT Law regimes development in Indonesia.

\section{Conclusion}

Referring to the analysis results and the research questions, the research concludes the following points.

1. The VAT policy on poultry products in Indonesia has experienced some changes following the development of the regime of the VAT Law in Indonesia. The VAT policy on poultry products has generally experienced some changes in the policy form and categorization. In the beginning, the categorization of the goods from the husbandry sector is based on fabrication and no fabrication, following the article 1 alphabet $\mathrm{c}$ of the Law No.8 year of 1983. Therefore, the VAT policy form for the poultry products in this regime of law is a non-taxable goods policy. There were some modifications on categorization and the policy form in the regime of the Law No.11 the year of 1994 which categorize the types of activities and goods produced. Therefore, the activity of producing poultry and eggs was categorized as non-taxable goods with different legal certainty, stated in article 4A. In the VAT Law No. 18 the year of 2000 regime, this categorization was remodified and the husbandry products such as poultry and eggs are no longer categorized according to the activity and the types of the goods but the characteristics of the goods, whether it is considered particular strategic goods or not. Based on the new categorization, poultry products were categorized as particular strategic goods according to article $16 \mathrm{~B}$ of this law 
regime and received VAT exemption. Finally, the categorization and VAT policy form was also remodified in the VAT Law No. 42 the year of 2009 regime. In this regime, poultry products such as meat and eggs were categorized as a group of goods which is very important for the citizens. Therefore, the poultry was considered as non-taxable goods, while the animals which are the source of these receives a different tax treatment.

2. Following the development in each regime of the law, there are several improvements in the policy form as well as the substantial characteristics. However, there has not been a significant improvement in the cost of taxation issue of VAT policy on poultry products throughout the VAT Law regimes in Indonesia.

\section{References}

[1] K. Von Grebmer, J. Bernstein, L. Hammond, F. Patterson, A. Sonntag, L. Klaus, J. Fahlbusch, O. Towey, C. Foley, S. Gitter, K. Ekstrom, and H. Fritschel. 2018. 2018 Global Hunger Index: Forced Migration and Hunger. Bonn and Dublin: Welthungerhilfe and Concern Worldwide.

[2] Rosdiana, Haula, Edi Slamet Irianto, dan Titi M. Putranti. Teori Pajak Pertambahan Nilai. Bogor: Ghalia Indonesia, 2011.

[3] Terra, Ben. Sales Taxation: The Case of Value Added Taxes in The European Community. Deventer-Boston: Kluwer Law and Taxation Publisher, 1988.

[4] Tait, Alan A. Value Added Tax: International Practice and Problems. Washington DC International Monetary Fund, 1988.

[5] Rosdiana, Haula, Edi Slamet Irianto. Panduan Lengkap Tata Cara Perpajakan di Indonesia. Jakarta: Visimedia, 2011.

[6] Rosdiana, Haula, Edi Slamet Irianto. Pengantar Ilmu Pajak: Kebijakan dan Implementasi di Indonesia. Jakarta: Rajagrafindo, 2012.

[7] Chattopadhyay, Saumen, Arindam Das-Gupta. The Compliance Cost of the Personal Income Tax and its Determinants. New Delhi: National Institute of Public Finance and Policy, (December) 2002.

[8] Rosdiana, Haula. "Rekonstruksi Konsepsi Supply-side Tax Policy”. Bisnis dan Birokrasi, Jurnal Ilmu Administrasi dan Organisasi 15(3), 2008: 202-205.

[9] Asshiddiqie, Jimly, dan Safa"e at, M. Ali. Theory Hans Kelsen Tentang Hukum, Cetakan I, Jakarta: Sekretariat Jendreral \& Kepaniteraan Makamah Konstitusi RI, 2006.

[10] Farida, Maria. Ilmu Perundang-Undangan. Yogyakarta: Kanisius, 1998.

[11] Manan, Bagir. Hukum Positif Indonesia (Suatu Kajian Teoritik). Yogyakarta: UII Press, 2004.

[12] Dunn, William N. Pengantar Analisis Kebijakan Publik: Edisi Kedua, 2003.

[13] Nugroho, Riant. Public Policy: Dinamika Kebijakan - Analisis Kebijakan Manajemen Kebijakan, Jakarta: PT Elex Media Computindo, 2011.

[14] Wagner, Claire, Barbara Kawulich, dan Mark Garner. Doing Social Research: A Global Context.UK: McGraw-Hill Education, 2012.

[15] Bungin, Burhan. Analisis Data Penelitian Kualitatif. Jakarta: Rajawali Pers, 2002.

[16]Creswell, John W. Qualitative Inquiry and Research Design. USA: SAGE Publications, Inc, 1998.

[17] Neuman, William Lawrence. Social Research Methods: Qualitative and Quantitative Approaches, 4th Edition. USA: Allyn \& Bacon, 2000. 